\title{
David Oliver: Junior doctors' working conditions are an urgent priority
}

\author{
David Oliver consultant in geriatrics and acute general medicine
}

Berkshire

A health service is nothing without its clinical workforce. The biggest existential threat to the NHS is a failure to retain existing clinicians or attract enough new ones. This damages morale, burns out those who stay, and compromises care quality. ${ }^{1}$

For junior doctors, the workforce crisis is becoming critical. We must act now to tackle it or reap the consequences for years. The length of training means that there's no reserve of ready replacements. Juniors are a precious human resource that we shouldn't casually alienate or squander. Their intellect, skills, and UK training are eminently exportable-right out of the NHS. Fewer trainees today means fewer GPs or consultants tomorrow, and we are already failing to fill many consultant posts in key specialties.

Junior doctors' intellect, skills, and UK training are eminently exportable-right out of the NHS

Junior doctors suffer from being a transient workforce-often only in one hospital or even town for a year at a time-and their concerns all too easy to brush aside. We need to wake up and take those concerns more seriously.

At the end of the foundation programme only a half of doctors are going straight into core or "run-through" training, including GP vocational training. ${ }^{2}$ Core training places in much needed specialty stems are increasingly unfilled. ${ }^{34}$ There's a knock-on effect of falling recruitment into higher specialist training. ${ }^{5}$

Some doctors stepping out of training programmes may rejoin later and continue an NHS career. Plenty will not. Others will decide against joining the most hard pressed and short staffed specialties (often those the health service needs most) in favour of better training, work-life balance, and work intensity.

We know plenty about what current junior doctors think about their own working lives, the problems they encounter, and the solutions they'd like to see implemented-in their own words, in official reports and surveys, and from social media. ${ }^{6-9}$ In the wake of the 2015-16 dispute over the (ultimately imposed) junior doctor contract, there was a contractual commitment and multi-agency code of conduct to tackle a range of concerns about working conditions. ${ }^{10}$
Is it too much to ask for some potentially quick and low cost wins? NHS employers should be able to ensure adequate access to rest facilities and to food and drink outside daytime hours; give adequate notice of rotas and flexibility in booking leave; minimise long commutes within regions; and ensure that people know their pay rates, that those rates are accurate, and that people don't have to battle over these rates. They should also make reasonable efforts to fill rota gaps, which in turn means continuing to welcome and support overseas medical graduates, ensuring that doctors don't feel bullied into filling the gaps, reducing the burden of repeated mandatory training and induction, and getting IT and logistics working better, to cut down on administrative work. There is also potential to reduce the burden of documentation of competencies in educational e-portfolios and the process of annual review of competence progression.

Such actions rely on better human resources management, on listening to and valuing doctors, and on showing some basic concern for their welfare. With responsibility for crucial actions distributed among many national and regional bodies and employing organisations, it's easy for everyone to pass the buck or bury their heads.

Doing nothing is not an option. Nor is doing something but far too slowly. Without concerted, urgent action, we won't have enough doctors to run viable services.

Competing interests: See www.bmj.com/about-bmj/freelancecontributors/david-oliver.

Provenance and peer review: Commissioned; not externally peer reviewed.

Follow David on Twitter: @mancunianmedic

1 Royal College of Physicians. Underfunded, underdoctored, overstretched: the NHS in 2016. Dec 2016. https://www.rcplondon.ac.uk/quidelines-policy/underfundedunderdoctored-overstretched-nhs-2016.

2 Foundation Programme. Career destination report 2016. Dec 2016. www. foundationprogramme.nhs.uk/download.asp?file=UKFPO_CDR_v7.pdf.

3 Health Education England. Specialty recruitment: round 1-acceptance and fill rate. Jul 2017. https://hee.nhs.uk/our-work/attracting-recruiting/medical-recruitment/specialtyrecruitment-round-1-acceptance-fill-rate. 
4 Rimmer A. BMA urges more career flexibility and better occupational support to fight workforce crisis. BMJ 2017;358:j4381. doi:10.1136/bmj.j4381 pmid:28935678.

5 Royal College of Physicians. 2015-16 census (UK consultants and higher specialty trainees). Dec 2016. https://www.rcplondon.ac.uk/projects/outputs/2015-16-census-ukconsultants-and-higher-specialty-trainees.

6 Royal College of Anaesthetists. 2017 survey of anaesthetists in training, as reported in RCoA: president's news, February 2017. www.rcoa.ac.uk/rcoa-presidents-news-february2017.

7 Royal College of Physicians. Being a junior doctor. Dec 2016. https://www.rcplondon.ac. uk/guidelines-policy/being-junior-doctor.
8 Royal College of Physicians. Keeping medicine brilliant. Dec 2016. https://www.rcplondon. ac.uk/guidelines-policy/keeping-medicine-brilliant.

9 Royal College of Physicians of Edinburgh. The medical registrar role: restoring its status and job satisfaction. https://www.rcpe.ac.uk/sites/default/files/medical-registrar-statementsep14-v2.pdf.

10 NHS Employers. Junior doctors terms and conditions of service. Mar 2017. www. nhsemployers.org/case-studies-and-resources/2017/03/junior-doctors-terms-andconditions-of-service-march-2017.

Published by the BMJ Publishing Group Limited. For permission to use (where not already granted under a licence) please go to http://group.bmj.com/group/rights-licensing/ permissions 